\title{
Which Way Lesotho? Some Reflections on the Political Geography Between Lesotho and South Africa.
}

\author{
Prof. Vusi Mashinini \\ Department of Geography \\ National University of Lesotho \\ P.O. Roma 180 \\ Lesotho
}

\begin{abstract}
The Kingdom of Lesotho is at the Crossroads. Since the formation of the Union of South Africa in 1910 up to date there has heen debate with regard to (lack of) necessity for Lesotho to hecome integrated with South Africa in order for Lesotho to have viability and sustainahility. While the issue of integration seemed offensive during the apartheid rule in South Africa, democratization in 1994 has provided hope that integration is worthy of consideration and national dialogue in Lesotho. This paper uses desk-top methodology to address the debate on integration and/or incorporation of Lesotho and South Africa and concludes bv pointing out that this dehate is impeded from heing conclusive because of its exclusive nature by failing to subject the issue to a national referendum.

The paper is divided into four sections. Section one provides the hackground. Section two is the historical overview of the debate. Section three is the dehate on the advantages and disadvantages of Lesotho 's incorporation/integration with South Africa. While four is the conclusion.
\end{abstract}




\section{Background}

Democratisation in South Africa in 1994 has hitherto brought about many a problem for the tiny Kingdom of Lesotho. While during the apartheid regime, Lesotho used to enjoy a special place in the United Nations Organisation and the international community at large as the fragile state desperate for survival and protection of its unitary state sovereignty "whithin the belly" of its more powerful police state of the Republic of South Africa; after 1994, this special treatment has waned and Lesotho largely has to make it (alone?) somehow. Many development agencies such as the Swedish International Development Agency (SIDA), and the United States Agency for International Development (USAID), United States Information Services (USIS), for example, have closed down their offices in Maseru, the capital of Lesotho, and moved to South Africa. The United Nations High Commission for Refugees closed down years ago and migrated to South Africa as well. The United Nations Development Programme has chopped down its support to Lesotho tremendously too (Mashinini and De Villiers, 2001).

\subsection{Negative Scenario}

On its part, democratic South Africa has added salt to wound. First, shortly after the coming into power of the African National Congress (ANC) led government in April 1994, Lesotho experienced a palace coup in August, 1994. The then King of Lesotho Letsie III, uniletarally declared the Basutoland Congress Party (BCP) government dissolved and replaced it with his own self-appointed government, called Provisional Council of State composed of six people - what was generally referred to as the "Six Pack" government in public circles in Lesotho. Much has been written about this political crisis in Lesotho (See Matlosa, 1994; Sekatle 1994; Southall \& Petlane, 1995). During this crisis, the South African Defence Force, (SADF) made several military air acrobatics into Lesotho along the border and over Maseru. 
Complaint sent to the government of South Africa by Lesotho about these acts was met with mockery that the boys were iust doing some military exercises. Of course, these acts by the SADF constituted violation of Lesotho's sovereignty over its air space.

Second, in January, 1995, the now late King Moshoeshoe II was returned to the throne. Much debate and controversies took place over the constitutionality of the rethronment. These controversies climaxed with one Mosotho man, who happened to be a lawyer and the then President of the Law society of Lesotho, launching a legal case against the government of Lesotho for having rethroned King Moshoeshoe II unconstitutionally. This case dragged for a long time and threatened to spark off instability in Lesotho. Again South Africa came into Lesotho and unilaterally took the said man to Pretoria for official reprimand (Mirror, 1995 a). Through this act, again democratic South Africa undermined the sovereignty of Lesotho and the power of the then BCP-led government in that it was by-passed in this matter.

Third, in April, 1995, the government of South Africa struck an agreement with the National Union of Mineworkers (NUM), a South African Trade Union. to grant some SADC migrants including Basotho mineworkers and those employed in other sectors of South Africa economy, over the past five (5) years starting from 1995 backwards, the status of permanent residents and that of full citizenship after a period of 5 years had been served as permanent resident by one. No negotiations were held with the government of Lesotho on this South Africa - NUM hatched scheme. Much debate existed about this act by the South African government and its potential impact on Lesotho's economy (see Matlosa, 1996; Gill, 1996; Weisfelder, 1997). Again, Lesotho's sovereignty was tarnished and so was the face of the government of Lesotho by South Africa's behaviour not using bilateral official channels to discuss this very important issue.

Fourth, South Africa has been working on the scheme to have the present borders removed. Government of Lesotho is not in favour of the idea. However, South Africa has had its own commission looking into this matter and the proposed scenario is 
that the border gates on the South Africa side be left open, so that, people can pass.

Fifth, after democratisation, the Southern African Development Community (SADC) countries openly recognized, in line with the rest of the world community, free education for all in South Africa. Some of these governments began to actively encourage and give financial support to students in their countries to go to South Africa for specialised and higher education not available at home. Paterson and Rouhani (1996) provide a useful statistical evidence of the magnitude of this phenomenon which they call "foreign students at South African Universities" and the implications it has for South Africa. One of the biggest complaints by South Africa was that it (South Africa) is at present not changing special rates on fees to foreign students and therefore directly subsidises their education in South Africa - a situation which is deemed unaffordable at present, given budget cuts by government to tertiary education. The SADC countries were therefore asked by South Africa to discuss a Draft Protocol on Education and Training for SADC that would facilitate member states to share accountability on tertiary education provision for SADC not later than June, 1997. This protocol was ratified by SADC member states in 2000. Lesotho features high in the list (fourth) of countries sending students to South Africa for specialized and higher education - an average of 155 in 1992. Since 1994 when democratisation took place this number has gone higher and stood at more than 10,000 in 2000 South Africa's insistance that it charge an 'enhanced' rate of fees to foreign students, affected Lesotho negatively because the per capita cost to higher education increased. Average per capita costs for Lesotho students stood at about M10,000 and R20,000 for undergraduate and postgraduate students respectively in 1998 (Mashinini and Mashinini, 2003). 


\subsection{Positive Scenario}

Not all acts committed by South Africa have been negative to Lesotho. Indeed, there have been many politically and economically highly significant endeavours which the former has done to salvage Lesotho's seemingly endless stream of crises.

First, South Africa together with Botswana and Zimbabwe played a leading role in the restoration of the democratically elected BCP government in Lesotho when it was outsed by King Letsie III in August, 1994. This contribution by South Africa, inter alia, insured the return of social stability which had particularly been shaken as the Lesotho Defence Force massacred five (5) innocent Basotho civilians in a demonstration to the palace against the Palace Coup. South Africa is, in fact, one of the three "quarantor states" to Lesotho's stability since then to date (Matlosa, 1994).

Second, South Africa, Botswana and Zimbabwe played a key role to ensure that King Moshoeshoe II was rethroned on 25th January, 1995 (Wesfelder, 1997). As Mirror (1995 b:1) put it " a tug of war is finally over between the Royal Family and the government after the pressure the three presidents of the neighbouring states have forced on the government to reinstate the king."

Third, in January, 1994, the Lesotho Defence Force (LDF) made a mutiny against the government in demand for a pay rise of $100 \%$. Failure to resolve this issue timeously on the part of the government of Lesotho, led to a worsening of crisis to a point where the LDF got divided between those in favour of continued strike action, namely, those based at the Makoanyane barracks visa-vis those who wanted a return to work, namely, those based at the Ramatjomose barracks. This disagreement became so serious that the two platoons took to the tops of the hills adjacent to their respective barracks and launched mortar attacks at each other. Much damage to both lives and property was incurred. Matlosa (1994:226) estimates that five (5) lives were lost and 11 people injured. It took the intervention of the three "guarantor states" of Botswana, Zimbabwe, South Africa, the Commonwealth 
Secretariat, the Organisation of Africa Unity (OAU), United Nations Development Programme, (UNDP) and the Donor Community to get a resettlement between these military factions and government (Weisfelder, 1997). Again, South Africa's contribution was magnanimous. The Citizen Newspaper of Johannesburg, Wednesday, 19 January (1994:2) captured commitment of South Africa to Lesotho then as follows:

\section{The South Africa government regarded the Lesotho} government as a legitimate and democratically elected government and any attempt to unseat it through force of arms would be unacceptable.

Fourth, in January, 1996, the then King Moshoeshoe II met a fatal car accident which claimed his life. South Africa played a crucial role in assisting with the flight logistics to air lift both the body of his late Majesty, royal family and dignitaries present to the top of Thaba-Bosiu for final burial and on assisting in general traffic control and management of the multitudes of people and vehicular traffic present.

Fifth, in winter, 1996, Lesotho experienced what was regarded as the worst snowfall of all time. The entire country's lowlands and mountains were enmeshed in snow of more than one metre high and the highlands were cut-off from the rest of the country for weeks on end. South Africa provided the air services to assist the Lesotho Defence Force to search for missing people, fly those in need to hospital in the lowlands and send food and other basic necessities to key emergency relief points in the mountains of Lesotho.

Sixth, in February, 1997, the police made a mutiny in solidarity with eight of their (senior?) colleagues who had been asked to appear in court against a charge of murder of their (senior?) colleagues in 1995 over a dispute on participation of the latter police in disciplinary measures taken against the strike action by the Lesotho Teachers Trade Union (LTTU) in that same year of 1995 on a request for improved salaries and terms of service by 
government of Lesotho. Peaceful measures by the government of Lesotho and other people of goodwill such as the opposition parties and the churches, for instance, failed to convince neither the concerned police officers to obey the law and appear in court nor their supporting police colleagues to stop the mutiny (Weisfelder 1997) Tension prevailed in the country especially in Maseru for two weeks (Weisfelder, 1997). Eventually the government of Lesotho announced on Wednesday, February, 12th, 1997, that the Lesotho Defence Force had been mandated to deal with the matter of the police mutiny accordingly. On Tursday, 13th February, 1997, the emissary of the three quarantor states of South Africa, Botswana and Zimbabwe arrived in Lesotho from Cape Town, South Africa, bearing a message of concern by the three countries that the government handle the matter of the policy mutiny with care; lest intervention by the military result in bloodshed.

Despite denials by the deputy Prime Minister of Lesotho on Radio Lesotho and BBC that Lesotho had sought assistance from South Africa, in an interview over channel 2 of South Africa Television on Monday 17th February, 1997, the Director General of Foreign Affairs of South Africa, indicated that Lesotho had indeed approached his government to assist the military quell trouble should the police mutiny prove beyond its control - a matter which, he conceded, his government watched with a close interest until the Lesotho military managed to resolve it through a storm operation code named "KISSWING" on Sunday, 16th February, 1997.

Seventh, on Monday the 9th June, 1997, Dr. Ntsu Mokhehle, the then Leader of the BCP and Prime Minister, called a press conference in which he announced, first, his resignation from the $\mathrm{BCP}$; second, that he had formed a new political party on Saturday, 7th June, 1997, called the Lesotho Congress for Democracy (LCD); and surprisingly, that he and those with whom they have formed LCD in parliament were 40 and constituted a majority in parliament; therefore, according to the constitution, that automatically entitled him not only to remain the Prime Minister of Lesotho, but, to transfer the BCP government to his side so that 
it became the LCD that governed legitimately (Southal and Fox, 1999; Matlosa, 1997).

This declaration by Dr. Ntsu Mokhehle was widely condemned by the BCP, leaders of various parties in Lesotho, the international community and indeed the nation at large, save, those who had loyalty to Ntsu Mokhehle (Matlosa, 1997). In reality Mokhehle's act amounted to theft of BCP government in a more subtle manner, but that which was reminiscent of the way the BNP stole the BCP government in 1970 (Khaketla, 1971). Mokhehle made a "constitutional coup" against the BCP government and ruled through the LCD until the general election of 1998. The election outcome which favored the LCD was disputed by other parties and resulted in violence and damage to property worth two billion Maloti and loss of many lives (Southal and Fox, 1999; Mashinini and De Villiers, 2001). Again the SADC intervention through South Africa and Botswana military forces intervened at high cost to restore stability in Lesotho (Southal and Fox, 1999; LSSJ; 1999). Until today, the SADC ministers for foreign affairs, headed by the South African foreign Minister, have since 1998 been engaged in a tireless effort to assist the Interim Political Authority (IPA) to prepare for the re-election envisaged for sometime in 2002.

The unfolding scenarios charted above in relation to the postapartheid South Africa-Lesotho relations since 1994 has, more than ever before, convinced some politicians, students of international relations; those of Political Geography, and those of Southern African Studies, and indeed interested observers from the public milieu, that the future of Lesotho lies nowhere else than in forging an integration with post-apartheid South Africa. The lead in thinking about Lesotho's future after apartheid was taken by the National University of Lesotho, through the Institute of Southern African Studies (ISAS) and the Department of Political and Administrative Studies which organised a series of seminars and conferences since the late 1980's into the early 1990's. These conferences were largely, but not exclusively, supported from the Swedish Government financially and resulted in an important book 
publication by Sejanamane \& Santho (1991). Other important contributions to this debate have been advanced by Sethala (1990); Mahao (1991); Southall (1991); Molise and Muller (1991); Lemon (1996); Love (1995; LUTARU, 1996).

\section{Lesotho's incorporation into South Africa: a historical overview}

The idea that Lesotho's future lies in its incorporation into its bigger, more economically and politically powerful neighbour, South Africa, is not new. Commenting on this issue of incorportation, the editorial of Sethala (1990:19) observed that:

Many people today are debating whether Lesotho should be incorporated into a free South Africa. This is not the first time in our history that such a question has been posed.

The editor went on to reproduce an article in Mochochonono newspaper of 1934 that discusses the issue of whether the then Basutoland ought to be incorporated into the then Union of South Africa. This discussion was a rejoinder to an earlier proposal hetched between the Boers and the British that Lesotho become part of the Union of South Africa in 1910; which idea Basotho rejected. Discussions on the history of and ideas behind the thought that Lesotho be incorporated into South Africa abound (see Marquard, 1971; Stevens, 1972; Eloff, 1979; Lemon, 1996 among others). Commenting on the issue of incorporation. Eloff (1979:37-39), writes that:

After 1910 the Orange Free State became part of the Union of South Africa and the border and land issue, Basutoland. was henceforth to be the responsibility of the central government. As early as 1913 the South African government had asked Britain to incorporate the three British protectorates (Basutoland, Bechuanaland 
and Swaziland) into the Union: The reason for this was mainly that the existence of future independent non-white states within the geographical unit of South Africa would constitute a contradiction.

It might be noted that the history of co-existence between these two countries since 1910 to date has been that of dichotomous parallel thinking on this issue. On its part South Africa of the pastapartheid years and that of today's democratic era has continued to display an attitude of treating Lesotho like any of its part at its convenience while the latter has relentlessly struggled to maintain its unitary sovereignity while at the same time continuing to be dependent on South Africa.

\section{The debate}

Contemporary day discussions on the future of Lesotho invariably crystallise on two major options, namely the maintenance of a unitary state sovereignty by Lesotho and attempts to enhance its development through negotiations with South Africa for closer regional economic arrangements vis-a-vis the option that Lesotho forgo its unitary state sovereignty and negotiate for total integration into South Africa to become its tenth province or part of the Free State Province.

In this debate there is the antagonistic viewpoint composed of those who reject the idea of incorporation. These are among others Lemon (1996; Mirror (1995 c); Pitso (1991); Mirror (1994 a, b, and c). Those who argue for incorporation such as UNDP (1995); Southall (1991); Mofeli (1989) represent the protagonst viewpoint in this debate and point out a number of advantages that Lesotho stands to gain if it were to be incorporated into South Africa.

Firstly, there are economic gains that are likely to be enjoyed (Cobbe, 1991). Lesotho's economic over dependence on South Africa is in terms of employment opportunities. More than 100,000 Basotho were employed in South Africa at any point in 
time in a year as migrant labours. Since the era of economic boycotts to the former apartheid regime in South Africa, Basotho migrant workers have been subjected to continuous retrenchment estimated at about 3,000 per annum during the early 1990's (Matlosa, 1991). Those who argue for Lesotho's incorporation into present-day South Africa hope that it might be possible to stop this retrenchment and its negative impacts on Lesotho once incorporation is effected, because it would no longer be necessary as all would be South Africans (Weisfelder, 1992). On their part, the migrant Basotho workers themselves would enjoy full employment rights with their formerly South African co-workers (Cobbe, 1991). There is an assumed free market for labour underlying the argument advanced above. It must be noted, however, that loss of revenue from the remittances will be incurred by Lesotho (Matlosa, 1996; Wesfeilder, 1992). Another likely economic gain might be in the field of industrial development.

Lesotho might have industrial development as a result of industrial deconcentration in the heartland of South Africa to the hinterland of which Lesotho would be a constituent part. Moreover, this industrial development might create linkages effects that might stimulate regional development in Lesotho through raw materials such as wool and mohair production as a result of demand from relocated industries that manufacture wool products. The industrial development within Lesotho would lessen the total dependence of the country on imports of all kinds of industrial goods from South Africa and reduce its import bill. It needs to be noted, however, that industrial location is a result of many linkages, both forward and backward, rather than policy per se. Despite the long years of the policy of decentralised industrial action, South Africa's industrialisation is still centralised. In fact even the few industries that attempted to relocate to Bantustans closed down and left because of lack of forward and backward linkages and the general problem of internal colonialism in intra regional political economy (Setsabi, 1993). Decaying carcasses of these industries can still be seen strewn all over, in places like Botsabelo, Thaba-Nchu and Qwa-Qwa in the Free State province, 
for example. One wonders if Lesotho might not experience a similar fate in this regard because it lacks an optimal mixture of forward and backward linkages and would be politically, and economically weaker than other regions.

Lesotho depends much on revenue generated from the Southern African Customs Union (SACU). If Lesotho were to be incorporated into South Africa, this revenue would be lost because SACU would seize operations with regard to it (Cobbe 1991).

Protagonists argue that Lesotho's natural resources are likely to be developed. Of special importance in this regard is resuscitation of the long closed Letseng-la-Terai diamond mine which was run by the De Beers mining company. The Letseng - Terai mine is now opened by a Lesotho company. Possibilities of opening up diamond mining operations in other places like Kao, for, instance, exist. The present multi million dollar Lesotho Highlands Water Project is another natural resource development project of major economic importance between Lesotho and South Africa, during the construction phases of all the phases of the projects scheduled to end in the year 2025 (Moeti, 1999), Lesotho enjoys the Highlands Water Development Fund - an annual sum of more than M60 million which it uses to finance community-based development projects in the country. When the actual transfer and sales of water to South Africa start this fund will stop (Moeti, 1999). Moreover, around M20 million is received monthly by Lesotho as payment of the water by South Africa. If however, Lesotho were to become incorporated into South Africa, this revenue might be lost because it might not become necessary any more for South Africa to pay for the transferred water.

The commercial sector has, for a long time, been in the hands of South African based firms. A newly striking feature is that the banking service is also fast reverting back to domination by South African banks. Recently Standard bank was replaced in January, 1997 by Nedbank. Since 1999, the Lesotho National Development Bank was taken over by the Standard Bank of South Africa and now operates under the name of Lesotho Bank 1999 (Mashinini and De Villiers, 2001). 
In any case, on their own accord, many middle and high class Basotho already do heavy investment banking in South Africa instead of Lesotho because interest rates are higher there. However, this promotes capital flight out of Lesotho and butresses its financial and commercial dependency (Mashinini and De Villiers, 2001). Protagonists hope that if Lesotho and South Africa incorporate Lesotho might get a better share from the commercial sector and the present phenomenon of capital flight through banking would be abated. Protagonists content that all these likely economically negative sides of the proposed incorporation would be over-compensated for by participation in the sharing of the larger South African economic cake to which Lesotho would be entitled (Wesfeilder, 1992).

There are also socio-politically motivated arguments raised by protagonsits to support the idea of Lesotho's incorporation into South Africa. On the political front, an argument is made premised on the long standing claim by Lesotho to the land lost/conquered and that ceded to the Boers both of which make up part of today's Free State Province of South Africa, back to Basotho now that apartheid has collapsed (Lelimo, 1998; Mokuku, 2000). Both Weisfelder (1992) and Mahao (1995) argue convincingly that such a claim would not be possible under the present Organization of African Unity (OAU) charter on international boundaries which is based on the principle of what Weisfelder (1992: 647) refers to as "uti possidentis" translated to "as you now possess" to which both Lesotho and South Africa are signitaries. Argument is made that, incorporation of Lesotho into South Africa would be an easier and more workable option for Lesotho to have access to this land more especially under the $\mathrm{BCP}$ and LCD rule, since the BCP has historically been the party with the slogan "Ea khutla Naha" translated as "the territory shall return" (Mahao, 1995). The Popular Front for Democracy (PFD) and the Communist Party of Lesotho (CPL) comment on this issue of claiming the conquered territory in these words: 
The pipe dream that Lesotho alone among all the nations of the world can successfully reclaim the territory it lost is not new: it is the same cheap stunt which the Basutoland Congress Party (BCP) used to garner votes in power the BCP 1993 elections (PFD \& CPL, 1995: 1).

From the sociological perspective it is argued that incorporation of Lesotho into South Africa would reunite the Basotho people in Lesotho and those of the Free State Province in South Africa with whom they have blood relationships but were separated by the colonial boundaries imposed by the British in collusion with the Boers (Mokuku, 2000). Other sociological elements to be gained are said to include, among others, access to cheaper and better social services like education. It is noted that many Basotho already send their children to schools with better facilities in South Africa (Wentzel, 2001). The National Manpower Development Secretariat, a Lesotho government department in charge of scholarships, financially supports people to study at South African Technikons, Colleges and Universities for specialized and/or higher education not available in Lesotho at present (Mashinini and Mashinini 2003).

The health services sector offers yet another socially important service which it is thought Lesotho might stand to gain from (Cobbe, 1991). At present many Basotho already seek better and specialised medical treatment in South Africa (Wentzel, 2001) along the border towns, in Bloemfontein and Betlhehem in the Free State Province, and Matatiele in the Eastern Cape province. The government owned and run Queen Elizabeth II Hospital in Maseru has long standing referral arrangements with Pelonomi Hospital in Bloemfontein (Mashinini and De Villiers, 2001).

Protagonists argue that Basotho have in the past, and will in future, continue to build the South African economy, yet they, unlike their co-workers in South Africa, are not entitled to old age pension schemes by the government of South Africa. If, however, Lesotho were to be incorporated into South Africa, the aged and infirm would be legible for social welfare subsidies at par with 
their contemporaries in South Africa (Cobbe, 1991). However, the question of social welfare emoluments, has to be thought out clearly within the context of the present and likely future third world economic environment dominated by World Bank and International Monetary Fund (IMF) financial lending based on Structural Adjustment Policies (SAPS) which are contemptuous of social welfare and prefer full privatisation of services.

Perhaps the single most important argument raised by protagonists relates to the possibility that Basotho of Lesotho would acquire citizenship as South Africans if Lesotho were to be incorporated (Cobbw, 1991; Southall, 1991). As citizens of South Africa, protagonists argue, Basotho would have free movement because the present borders between the two countries would be abolished. Basotho would no longer be retrenched at work, they would compete at par in the labour market; they would get similar pension and old age schemes; they would even have the prerogative to decide to migrate from Lesotho and settle anywhere in South Africa with their families if they so wished. The list is not exhaustive of promises to be gained. Basotho's appetites for the lucrativeness of acquisition of South Africa citizenship by Basotho was whetted in April, 1995 by the unilateral decision reached jointly by the South African Government and its trade union, the National Union of Mineworkers (NUM), to grant the status of permanent residence to all Basotho who have been working in South Africa, especially in mining, five years and backwards of 1995 (Mokuku, 2000, Weisfelder, 1997). Some of these promises of possible gains need to be thought out clearly in their proper perspectives. For example, the phenomenon of retrenchment occurred in Lesotho itself when SAPS were first adopted in the late eighties (Matlosa, 1990). Moreover, it is one thing to carry an identification document that declares one either a Permanent Resident or even citizen of South Africa; and quite another to get that document to enable one to acquire residential land in South Africa. It needs to be noted that the majority of land in South Africa is privately owned and mechanisms to acquire it for (re-) settlement purpose are very difficult. Since independence, 
the ANC government has been desperately trying to get access to land to effect settlement of black people as promised in the Reconstruction and Development Programme (RDP) without much success (Ntsebenza and Hendriks, 2000). How then can one hope that an added burden of people from Lesotho might make the situation any better? The likely scenario is that people below the middle class in Lesotho - a majority at present -might move from a rural or urban village in Lesotho directly to a squatter camp in a town of their preference in South Africa, where the waiting list for decent housing is already long beyond tolerance levels as shown by the increasing wave of "illegal" land occupations by some communities. The upper and middle class cadre in Lesotho are themselves already purchasing houses and even farms anywhere they like in South Africa without incorportation because they can afford the going prices and tenure condition (Murray, 2000). Some Basotho even have illegal double/dual citizenship in Lesotho and South Africa (Mokuku, 2000).

\section{Conclusion}

This paper has attempted to highlight the fact that South Africa and Lesotho have co-existed throughout their histories to date. This co-existence has however, been highly unequal, with South Africa not only calling the shots, as it were, but on many occasions imposing and dictating terms to Lesotho. On its part, Lesotho has always had little choice but to become conformist to South Africa's wishes because of its economic over-dependence on South Africa and fear of the military might of the latter (Matlosa, 1997; Machobane, 2001:69-71).

However, the collapse of apartheid and attainment of democratisation in Southa Africa has sparked off both a feeling and desire in some circles within Lesotho that perhaps forging an incorporation into South Africa might be the best option to safeguard and spearhead Lesotho's present and future development towards a more fruitful and secure direction. The United Nations 
Development Programme (UNDP) (1995: iv) hones this point in these works:

\begin{abstract}
Sooner rather than later, it is vital that Lesotho acts quickly in order to avoid becoming marginalised. Unless Lesotho acts, at the very least, negotiates favourable access to the South African labour market, the mountain kingdom will end up suffering the same kind of economic stagnation as the homeland areas suffered under the old apartheid regime.
\end{abstract}

This paper highlights the fact that at present, there is no unanimity on the question of incorporation within Lesotho. While much debate is lively among urban-based intellectuals and politicians about this possibility, the ordinary urban and rural Basotho have not yet been formally consulted to pronounce themselves on this issue. Neither has there been a clearly articulated statement of the position of South Africa on it. According to the ANC (1992), however, Lesotho was not shaded as one of the ten proposed regions for democratic South Africa.

This paper notes with concern, the fact that incorporation of Lesotho into South Africa would imply direct loss of unitary state sovereignty, nation-statehood and nationalism by Lesotho and all the accompanying rights both international and national that go with the rights of sovereignty. The paper notes with equal concern, the ever overwhelming economic, social, political and military dependence of Lesotho on South Africa. The paper concludes that, in order to promote an inclusive and conclusive debate, the question of Lesotho's integration/incorporation with South Africa should be subjected to a national referendum. 


\section{References}

Gobbe, J. (1991): "Lesotho: What will happen after apartheid goes? Africa Today. 38 (1):18-32

Eloff, C. (1979): The so-called Conquered Territory: disputed border area between the Oranue Free State (Republic of South Africa) and Basutoland). Human Resources Research Council. Central publications series No.l Pretoria.

Gill, S. (1996): "Labour migration and related issues." Work for Justice (46): 1-3.

Khaketla, B. (1971): Lesotho 1970: An African Coup under the microscope. Masechele Khaketla. Morija.

Lelimo, M. (1998): The Conquered Territory: its time for an answer. Morija Museum and Archives. Morija.

Lemon, A. (1996) "Lesotho and the new South Africa: the question of incorporation" The Geographical Journal.

Lesotho Social Sciences Journal (LSSJ) (1999): Miscellaneous articles in the special issue on the Post 1998 general election conflict. 5(1).

Love, R. (1995) "Lesotho: Inner to outer Periphery." Review of African Political Economy. 67 (23).

Lutaru Workshop (1996): The Economic and Political future of Lesotho. NUL, Roma. 23rd February.

Machobane, L. BBJ. (2001): Kings Knights: Military Governance in the Kingdom of Lesotho, 1986-1993. Institute of Southern African Studies. Roma. 
Mahao, N. (1991) "Some legal and political issues in respect of Lesotho's options in the context of a future democratic South Africa." In Santho, S and Sejanamane, M.(eds): Southern Africa after apartheid. SAPES. Harare. Pp.194-208.

Mahao, N. (1995): Khokahanyo ea Lesotho ho S.A. hase boinehelo." Moeletsi oa Basotho. vol. 63, no. 3066, 23 'Mesa. p.8

Marguard, L. (1971): A Federation of South Africa. Oxford University Press. Cape Town.

Mashinini V.and De Villiers, G. (2001): "Lesotho's sustainable development challenges for the 21st century: A geo-political perspective." South African Geographical Journal. 83(1) 56-63.

Mashinini A. and Mashinini, V. (2003): "The changing pattern of students flows for higher education between Lesotho and South Africa." African Insight. 33(4): 19-25.

Matlosa, K. (1996): "Lesotho, What is the future?" an interview in Work for Justice, no. 46, April. pp. 4-6.

Matlosa, K. (1990): Structural adiustment and the employment challenge in Lesotho. NUL, Roma.

Matlosa, K. (1991):"Retrenchment of Basotho mineworkers in South Africa and the capacity of Lesotho's rural informal sector employment." NUL. Journal of Research. 2:27-48.

Matlosa, K. (1997): "Vulnerability and Viability of small states in Southern Africa in Post-Apartheid era: Is South Africa still "Big Brother?". A paper presented to the Social Sciences Seminar. NUL. Roma. 
Matlosa, K. (1994): "The recent political crisis in Lesotho and the role of foreign powers" Africa Insight. 24(4).

Mirror (1994a): Issue of the ceded land and picture", vol. 6, no. 59 Friday March 11, p.7.

Mirror (1994b): "N.U.M.'s Motlatsi caught in no man's land. vol. 7 , no.3, Friday 18, p. 1

Mirror (1994c):"Motlatsi is offside - Senators." vol. 7, no.3, Friday. 18 p.l

Mirror (1995a): "The position of the Monarch challenged." Vol.7, no. 36, March 31, p.1.

Mirror (1995b): "A tug of war finally over; Moshoeshoe II regains the throne." Vol. 7, no. 30, January 20, p.1

Mirror (1995c): "N.U.M. invades Lesotho." vol. 8, no.72, November, 15 p.l.

Moeti, L. (1999): "Paradox of Water resource development: Lesotho Highlands Water Project." South-South Journal of culture and Development. 1(2):1-20.

Mokuku, M. (2000): "Dr. Jeckyll and Mr. Hyde: Basotho citizenship and national identity strategies across the Lesotho-South Africa border." NUL Journal of Research. $8: 75-103$

Murray, C. (2000): Changing livelihoods: The Free State, 1990's." African Studies. 59 (1): 115-142.

Mofeli, C.. (1998) "Mofeli argues for federation with South Africa." The Mirror. vol. 2, no. 11, p.1 December. 
Molise, M. \& Muller, T. (1991): "Would Lesotho sink without apartheid? "Sethala, vol. 5, no.33.

Ntsebenza, L. and Hendriks, F. (2000): The Paradox of South Africas land reform policy: failed decolonisation?" A paper presented to the SARIPS Colloquirim in Harare, 20-23 September, 2000.

Pitso, M. (1991): "Lesotho should not be integrated into non-racial South Africa" The Mirror. vol. 3, no.39. 16 August.

Rouhani, S. \& Paterson, A (1996): "Foreign students at South African Universities." Development Southern Africa. 13(2): 288-290.

Sejanamane, M. \& Santho, S. (eds) (1991): Southern Africa after Apartheid. SAPES Harare.

Sekatle, P. (1994): "King or Country: The Lesotho crisis of August." Indicator South Africa. 12 (1)

Sethala (1990): "Should Lesotho be incorporated into a Free South Africa?" pp. 19-20.

Setsabi, S. (1993): Alternative strategies for rural industrialization and regional decentralization: Lessons from South Africa. A paper presented at the RUPSEA workshop at Maseru Cabanas, Lesotho.

Southall, R. (1991): "Lesotho and the re-integration of South Africa." In Santho and Sejanamane, M. (eds.): Southern Africa after Apartheid. SAPE Harare. 
Stevens, R (1972): "The history of the Anglo-South African conflict over the proposed incorporation of the High Commission territories." In Potholin P. and Dale R. (eds.): Southern Africa in Perspective: Essay's in regional politics. New York \& London.

The African Nation Congress (ANC) (1992): Ten proposed Regions for a United South Africa. Centre for Development Studies. University of the Western Cape. Cape Town.

The Citizen (1994). "New Lesotho clashes." Johannesburg. Wednesday 19th January. Pp. 1-2.

The Popular Front for Democracy (PFD) and the Communist Party of Lesotho (CPL) (1995): "Joint Statement by the PFD and CPL." The Mirror. Vol.8 no.50, p.1.

United Nations Development Programme (UNDP) (1995): The Impact of changes in South Africa on the development prospects of Lesotho. UNDP. Maseru.

Weisfelder, R. (1992): "Lesotho and the Inner Periphery in the New South Africa." The Journal of Modern African Studies. 30 (4): 643-663.

Weisfelder, R. (1997): "Why Lesotho needs a distinctive diplomatic strategy, but has not found an appropriate format." Africa Insight. 27(1): 32-43.

Wentzel, M. 2001: "Cross-border movement between Lesotho and South Africa: Some perspectives". Lesotho 2000: Public perceptions and perspectives. Edited by Rule, S. and Mapetla, N. HSRC. Pretoria. Pp. 167-180. 


\section{(c) (1) (9)}

This work is licensed under a

Creative Commons

Attribution - NonCommercial - NoDerivs 3.0 License.

To view a copy of the license please see:

http://creativecommons.org/licenses/bv-nc-nd/3.0/ 